\title{
PREVALENSI STUNTING PADA 1000 HARI PERTAMA KEHIDUPAN
}

\author{
Rahmadiyat Hidayat ${ }^{1}$ \\ ${ }^{1}$ Universitas Airlangga, Jl. Mulyosari Surabaya, Indonesia
}

\begin{abstract}
The effort to reducing the prevalence of stunting continue to be done especially on 1000 the first days of life in order to prevent the emergence of the impact of stunting in the period of the next life. Pregnant women, breastfeeding mothers, newborns and children aged under two years (baduta) target group is to improve the quality of life at 1000 the first days of life.This study was know the risk factors that relating to characteristics 1000 maternal and child in the period of the first days of life to events stunting of children aged 6-24 months in Surabaya City. Research observational design control unmatched case study by approaching retrospective. The subject of study you are the 6-24 meet the criteria of the inclusion of 100 baduta stunting $(T B / U<-2 S D)$ and 100 baduta normal $(T B / U \geq-2 S D)$ in Surabaya City. Based on the results of the analysis bivariat characteristic of a mother and children a factor is risk stunting nutritional status of early pregnancy $(p=0.047 ;$ OR=1.95), the status KEK $(p=0.018 ; O R=2.15)$; the increase in weight for pregnant $(p=0.56 ; O R=1.18)$; the frequency of monitoring growth $(p=0.637 ;$ OR=1.24); the handling of childbirth ( $p=0.825 ; O R=1.1) ; \operatorname{IMD}(p=0.159 ;$ OR=1.55); breastfeeding exclusive ( $p=0.145 ;$ OR $=1.53)$; and frequency monitoring growth $(p=0.08 ;$ OR $=1.66)$. With logistic regression multivariate analysis shows that there is no variable free directly influence to events stunting. The results the analysis there was no correlation welfare between a gestation period of the baduta age to stunting. Characteristic of a mother and child that has an effect greater as the stunting is increasing weight of pregnant mothers during pregnancy because it has the largest statistics $z$ (0.867). Efforts to prevent and reduce stunting must be implemented in all the period of 1000 HPK (pregnancy, childbirth, and the age of baduta).
\end{abstract}

Keywords: Stunting, Pregnancy, Childbirth, Age Baduta.

\begin{abstract}
ABSTRAK
Upaya penurunan prevalensi stunting terus dilakukan terutama pada 1000 hari pertama kehidupan guna mencegah timbulnya dampak stunting pada periode kehidupan selanjutnya. Kelompok sasaran ibu hamil, ibu menyusui, bayi baru lahir dan balita (baduta) adalah peningkatan kualitas hidup 1000 hari pertama kehidupan. pada periode hari pertama kehidupan terhadap kejadian stunting pada anak usia 6-24 bulan di Kota Surabaya. Desain penelitian observasional control unmatched case study dengan pendekatan retrospektif. Subyek penelitian anda adalah 6-24 yang memenuhi kriteria inklusi 100 baduta stunting (TB/U < -2 SD) dan 100 baduta normal (TB/U -2 SD) di Kota Surabaya. Berdasarkan hasil analisis bivariat karakteristik ibu dan anak faktor risiko stunting adalah status gizi awal kehamilan ( $\mathrm{p}=0,047$; OR=1,95), status KEK ( $\mathrm{p}=0,018$; $\mathrm{OR}=2,15)$; peningkatan berat badan ibu hamil $(\mathrm{p}=0,56 ; \mathrm{OR}=1,18)$; frekuensi pemantauan pertumbuhan $(\mathrm{p}=0,637 ; \mathrm{OR}=1,24)$; penanganan persalinan $(\mathrm{p}=0,825$; $\mathrm{OR}=1,1)$; IMD ( $\mathrm{p}=0,159$; ATAU=1,55); ASI eksklusif ( $\mathrm{p}=0,145 ; \mathrm{OR}=1,53)$; dan frekuensi pemantauan pertumbuhan $(\mathrm{p}=0,08 ; \mathrm{OR}=1,66)$. Dengan analisis multivariat regresi logistik menunjukkan bahwa tidak ada variabel bebas yang berpengaruh langsung terhadap kejadian stunting. Hasil analisis tidak ada hubungan kesejahteraan antara masa gestasi usia baduta dengan stunting. Karakteristik ibu dan anak yang berpengaruh lebih besar sebagai stunting adalah peningkatan berat badan ibu hamil selama kehamilan karena memiliki statistik terbesar z $(0,867)$. Upaya pencegahan dan pengurangan stunting harus dilaksanakan pada semua periode 1000 HPK (hamil, nifas, dan usia baduta).
\end{abstract}

Kata Kunci: Stunting, Kehamilan, Melahirkan, Usia Baduta. 


\section{INTRODUCTION}

Stunting merupakan salah satu jenis malnutrisi yang terjadi pada anak akibat akumulasi efek kurang asupan gizi dan ada infeksi pada anak sejak proses kehamilan. Stunting digunakan sebagai indikator kondisi lingkungan yang buruk atau restriksi pertumbuhan anak yang terjadi dalam jangka waktu lama. WHO menyatakan, kalau stunting itu menggambarkan terjadinya masalah gizi secara kronis (WHO, 2010).

Prevalensi stunting di seluruh dunia mencapai $23,8 \%$ atau sekitar 159 juta anak mengalami stunting. Prevalensi stunting ini menurun dibanding tahun 1990 yaitu sebesar 39,6\% (Haddad L, 2016). Sedangkan prevalensi stunting di Indonesia berdasarkan hasil Riskesdas 2013, sebesar 37,2\% dan Provinsi Jawa Timur di atas 40\% melebihi prevalensi stunting nasional (RISKESDAS, 2013).

Prevalensi balita stunting versi World Health Organization (WHO), hasilnya Indonesia termasuk ke dalam negara ketiga dengan prevalensi tertinggi di regional Asia Tenggara/SouthEast Asia Regional (SEAR). Rata-rata prevalensi balita stunting di Indonesia tahun 2005-2017 adalah 36,4\% (Kementerian Kesehatan Republik Indonesia, 2018). Walaupun data terakhir Riset Kesehatan Dasar (Riskesdas) tahun 2018 menunjukkan angka yang cukup menggembirakan terkait masalah stunting, yaitu angka stunting atau anak tumbuh pendek turun dari 37,2 persen (2013) menjadi 30,8 persen (2018) (Riset Kesehatan Dasar (RISKESDAS), 2019).

Upaya penurunan prevalensi stunting terus dilakukan pada 1000 hari pertama kehidupan atau windows opportunity (dari masa konsepsi hingga usia 2 tahun) untuk mencegah munculnya dampak stunting seperti gangguan perkembangan fisik dan kognitif, penurunan kapasitas dan produktivitas, gangguan kesehatan dan peningkatan risiko timbulnya penyakit degeneratif (De Onis et al., 2013). Pemerintah Indonesia melalui Millenium Challenge Corporation dari Amerika Serikat telah melaksanakan inisiatif untuk mengurangi anak pendek lewat Program Kesehatan dan Gizi Berbasis Masyarakat (PKGBM). Program untuk mengurangi anak pendek ini berupaya meningkatkan permintaan akan perlengkapan yang diperlukan untuk mengurangi jumlah anak pendek (stunting). Program ini diharapkan dapat menjangkau 2,9 juta anak di 5.400 desa dan memberikan manfaat besar bagi seluruh keluarga di 11 provinsi, 64 Kota, dan 499 kecamatan (Program Nasional Pemberdayaan Masyarakat Mandiri (PNPM), 2013).

Kota Surabaya merupakan satu dari 8 Kota di Provinsi Jawa Timur yang mendapatkan program tersebut. PKGBM di Kota Surabaya dimulai sejak tahun 2015, di 7 kecamatan dari 
13 kecamatan yang ada. Penetapan ini berdasarkan indikator permasalahan kesehatan dan gizi yang masih tinggi di Kota Surabaya (Badan Pusat Statistik Kota Surabaya, 2018). Tujuan penelitian ialah mengetahui faktor risiko yang berhubungan dengan karakteristik ibu dan anak pada periode 1000 hari pertama kehidupan terhadap kejadian stunting anak usia 6-24 bulan di Kota Surabaya. Karakteristik ibu dan anak pada periode 1000 Hari Pertama Kehidupan ini meliputi karakteristik periode kehamilan (status gizi awal kehamilan, status KEK, kenaikan berat badan selama kehamilan, dan frekuensi pemeriksaan kehamilan); periode persalinan (penanganan persalinan, perawatan persalinan, dan konseling pemberian makan bayi dan anak); dan periode usia bawah dua tahun (inisiasi menyusu dini, ASI eksklusif, dan pemantauan pertumbuhan).

\section{METHOD}

Jenis penelitian ini adalah penelitian observasional dengan rancangan Unmatched casecontrol study (studi kasus-kontrol tanpa matching). Penelitian dilaksanakan di Kota Surabaya Provinsi Jawa Timur, pada 3 dari 7 kecamatan wilayah PKGBM, yaitu Surabaya, Jombang, dan Jember. Pemilihan lokasi secara Purposive Sampling, mempertimbangkan keterjangkauan, kesamaan sosiodemografi, ketersediaan sarana dan prasarana kesehatan.

Pendekatan yang digunakan dalam penelitian ini melalui pendekatan retrospektif. Penelitian dimulai dengan mengidentifikasi subyek dengan efek (kelompok kasus) dan tanpa efek (kelompok kontrol). Karakteristik ibu dan anak ditelusuri secara retrospektif pada kedua kelompok kemudian membandingkan kedua kelompok tersebut. Kelompok kasus adalah anak usia 6-24 bulan stunting sedangkan kelompok kontrol adalah anak usia 6-24 bulan normal, kemudian diteliti pengaruh karakteristik ibu dan anak pada periode 1000 hari pertama kehidupan terhadap kejadian stunting.

Populasi dalam penelitian ini adalah ibu yang mempunyai anak baduta (usia 6-24 bulan) di Surabaya, Jombang, dan Jember. Subyek penelitian adalah seluruh anak berusia 6-24 bulan yang tercatat sebagai sasaran real balita di 3 wilayah kecamatan daerah PKGBM. Jumlah subjek penelitian dihitung berdasarkan perhitungan two population proportions (Lemeshow S., Hosmer DW., 1997). Jumlah sampel memperhitungkan besar sampel yang dibutuhkan dari masing-masing variabel. Berdasarkan hasil perhitungan tersebut, maka besar sampel yang diambil adalah yang terbesar yaitu 99,9 dibulatkan menjadi 100 sampel minimal. Jadi, jumlah responden adalah 100 anak pada masing-masing kelompok. Kriteria inklusi yaitu anak kandung responden, bila keluarga memiliki lebih dari satu anak usia 6-24 bulan yang diambil adalah anak yang berusia paling muda, ibu mempunyai catatan riwayat kesehatan dan gizi ibu dan 
anak (buku KIA/kohort ibu dan anak), kehamilan tunggal, anak dalam keadaan sehat pada saat penelitian, dan ibu bersedia menjadi responden dengan menandatangani informed consent.

Pengambilan subjek penelitian dengan terlebih dahulu melakukan skrining status gizi pada anak usia 6-24 bulan di 27 desa pada 3 kecamatan. Subjek yang memenuhi kriteria inklusi dijadikan sampel. Penentuan jumlah sampel di setiap desa secara purposive dengan proporsional random sampling. Pengumpulan data dengan cara pengukuran antropometri, wawancara, pengamatan langsung, dan pencatatan data sekunder yang bersumber dari buku Kesehatan Ibu Anak (KIA) dan kohort ibu dan anak dengan melakukan kunjungan langsung ke rumah responden.

Karakteristik ibu dan anak dibagi 3, yaitu periode kehamilan (status gizi awal kehamilan, status KEK, kenaikan berat badan selama kehamilan, dan frekuensi pemeriksaan kehamilan); periode persalinan (penanganan persalinan, perawatan persalinan, dan konseling PMBA); periode usia baduta (inisiasi menyusu dini, ASI Eksklusif, dan pemantauan pertumbuhan).

Teknik pengolahan meliputi data (primer dan sekunder) dikumpulkan, diedit untuk memastikan data sudah benar dan lengkap, jawaban kuesioner diberi kode, kemudian entry data yaitu memasukkan ke dalam software, dan cleaning untuk membersihkan data agar tidak double. Analisis data menggunakan Microsoft Excel dan program statistik (stata) versi 13. Adapun cara analisis data yang dilakukan dalam penelitian ini ialah: (1) Analisis univariat untuk mendeskripsikan data karakteristik responden, variabel periode kehamilan (status gizi ibu pada awal kehamilan, status KEK, frekuensi pemeriksaan kehamilan, dan kenaikan berat badan selama kehamilan), variabel periode persalinan (penanganan persalinan, perawatan persalinan, konseling PMBA), variabel periode baduta (IMD, ASI Eksklusif, pemantauan pertumbuhan) dan stunting yang ditampilkan berupa distribusi frekuensi dan persentase. (2) Analisis bivariat, dilakukan untuk menguji hubungan antar 2 variabel (variabel bebas dan variabel terikat) menggunakan uji Chi-square untuk mengetahui hubungan antara dua variabel. Kemudian dilakukan uji Odds Ratio (OR) untuk mengetahui besar risiko variabel bebas terhadap kejadian stunting. (3) Analisis multivariat. Apabila hasil perhitungan analisis bivariat menunjukkan hubungan yang bermakna secara statistik $(\mathrm{p}<0,05)$ dan kemaknaan biologis, maka dilanjutkan menggunakan analisis multivariat (Riyanto, 2011). Adapun, analisis multivariat ini dilakukan untuk melihat hubungan antara variabel bebas dengan variabel terikat secara bersama-sama munggunakan uji regresi logistik. 


\section{RESULTS AND DISCUSSION}

\section{Karakteristik Subjek Penelitian}

Hasil karaktersitik responden berdasarkan kondisi sosial ekonomi didapatkan: pendidikan kedua orangtua lebih banyak pada kategori rendah pada kasus dan kontrol. Pekerjaan kedua orangtua lebih banyak pekerjaan tidak tetap. Persentase pekerjaan tidak tetap ayah pada kontrol (85\%), dan kasus (86\%). Pekerjaan ibu tidak tetap untuk kelompok kontrol (92\%) dan kelompok kasus (96\%). Rata-rata pendapatan responden terbesar pada kategori <1 juta pada kontrol sebesar $48 \%$ dan kasus sebesar 51\%. Rendahnya pendapatan ini sesuai dengan pekerjaan orangtua yang sebagian besar sebagai petani dan buruh atau pekerjaan tidak tetap lainnya. Untuk pendapatan petani di Kota Surabaya hanya Rp. 377.166,67 per bulan dan masih jauh di bawah UMR Kota Surabaya Rp. 2.108.996 (Badan Pusat Statistik Kota Surabaya, 2018).

\section{Karakteristik Kesehatan dan Gizi Ibu}

Pada Tabel 1, terlihat data karakteristik responden berdasar kesehatan dan gizi ibu. Usia kehamilan atau lamanya kehamilan responden lebih banyak pada kategori aterm (umur kehamilan 38-42 minggu). Pada kelompok kontrol sebesar 59\% dan kelompok kasus sebesar $51 \%$. Persentase usia ibu awal kehamilan terbesar pada kategori 20-35 tahun, pada kelompok kontrol sebesar 78\% dan kelompok kasus sebesar $67 \%$.

Tabel 1. Karakteristik Responden Berdasar Kesehatan dan Gizi Ibu

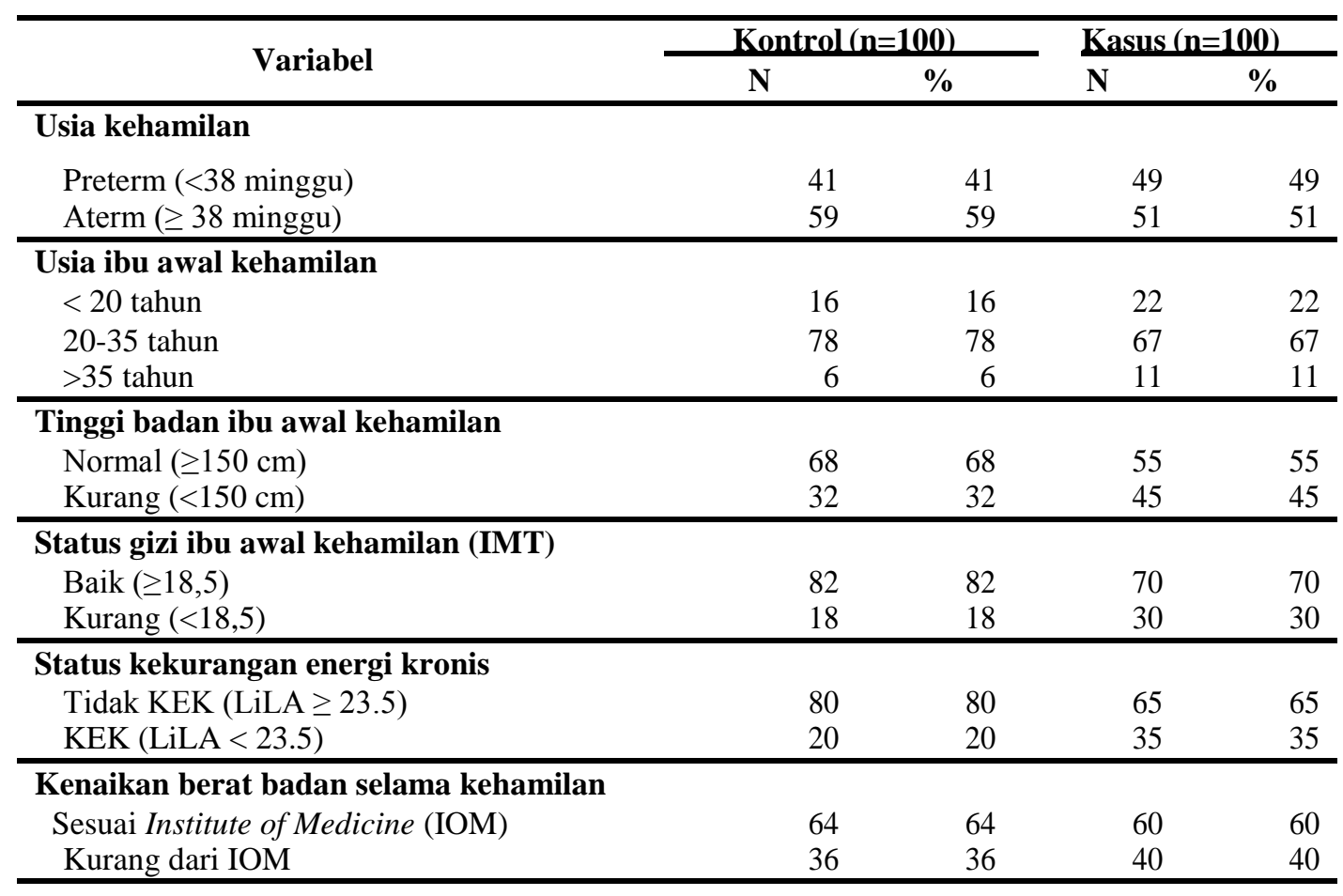




\begin{tabular}{|c|c|c|c|c|}
\hline \multirow{2}{*}{ Variabel } & \multicolumn{2}{|c|}{ Kontrol (n=100) } & \multicolumn{2}{|c|}{$\underline{\operatorname{Kasus}(n=100)}$} \\
\hline & $\mathbf{N}$ & $\%$ & $\mathbf{N}$ & $\%$ \\
\hline \multicolumn{5}{|c|}{ Frekuensi pemeriksaan kehamilan } \\
\hline Baik ( $\geq 4$ kali) & 91 & 91 & 89 & 89 \\
\hline Tidak (<4 kali) & 9 & 9 & 11 & 11 \\
\hline \multicolumn{5}{|l|}{ Penanganan persalinan } \\
\hline Tenaga medis & 89 & 89 & 88 & 88 \\
\hline Tenaga non medis & 11 & 11 & 12 & 12 \\
\hline \multicolumn{5}{|l|}{ Perawatan persalinan } \\
\hline Perawatan & 99 & 99 & 100 & 100 \\
\hline Tidak perawatan & 1 & 1 & 0 & 0 \\
\hline \multicolumn{5}{|l|}{ Konseling PMBA } \\
\hline Mendapat konseling & 100 & 100 & 100 & 100 \\
\hline Tidak mendapat konseling & 0 & 0 & 0 & 0 \\
\hline
\end{tabular}

Persentase ibu dengan tinggi badan normal $(>=150 \mathrm{~cm})$ lebih banyak dibandingkan dengan ibu yang memiliki tinggi badan kurang. Pada kelompok kontrol persentasinya 68\% dan kelompok kasus sebesar 55\%. Sedangkaan untuk ibu yang memiliki status gizi baik lebih banyak dibandingkan dengan ibu yang memiliki status gizi kurang, persentase untuk kelompok kontrol sebesar $82 \%$ dan kelompok kasus sebesar $70 \%$.

Ibu yang tidak menderita kekurangan energi kronis (KEK) persentasenya lebih besar dari ibu yang KEK, hasil deskriptif menunjukkan status KEK pada kelompok kontrol sebesar $80 \%$ dan kelompok kasus sebsesar 65\%. Kenaikan berat badan ibu yang sesuai Institute of Medicine (IOM) lebih besar daripada yang kurang dari IOM. Pada kelompok kontrol sebesar $64 \%$ dan kasus sebsesar $60 \%$.

Ibu yang melakukan pemeriksaan kehamilan lebih dari 4 kali persentasenya lebih besar, pada kelompok kontrol sebesar 91\% dan kelompok kasus sebesar 89\%. Penanganan persalinan oleh tenaga medis menunjukan persentase lebih besar, pada kelompok kontrol sebesar $89 \%$ dan kelompok kasus sebesar 88\%. Sedangkan untuk ibu yang mendapat perawatan persalinan pada kelompok kontrol sebesar 99\% dan kelompok kasus ternyata semua ibu $(100 \%)$ mendapatkan perawatan persalinan tenaga kesehatan.

\section{Karakteristik Kesehatan dan Gizi Anak Usia 6-24 Bulan}

Berdasarkan jenis kelamin, seperti terlihat pada Tabel 2, ternyata perempuan lebih banyak pada kelompok kontrol (54\%) dan laki-laki lebih banyak pada kelompok kasus (58\%). Usia terbanyak pada usia 6-11 bulan pada kelompok kontrol (38\%) dan 18-23 bulan pada kelompok kasus (40\%). Persentase anak yang medapat Inisiasi Menyusui Dini (IMD), yaitu sebesar 76\% kelompok kontrol dan 67\% kelompok kasus. 
Tabel 2. Karakteristik Responden Berdasar Kesehatan dan Gizi Anak Usia 6-24 Bulan

\begin{tabular}{|c|c|c|c|c|}
\hline \multirow{2}{*}{ Variabel } & \multicolumn{2}{|c|}{ Kontrol (n=100) } & \multicolumn{2}{|c|}{ Kasus (n=100) } \\
\hline & $\mathbf{N}$ & $\%$ & $\mathbf{N}$ & $\%$ \\
\hline \multicolumn{5}{|l|}{ Jenis kelamin anak } \\
\hline Laki-laki & 46 & 46 & 58 & 58 \\
\hline Perempuan & 54 & 54 & 42 & 42 \\
\hline \multicolumn{5}{|l|}{ Usia anak } \\
\hline 6-11 bulan & 38 & 38 & 22 & 22 \\
\hline 12-17 bulan & 31 & 31 & 34 & 34 \\
\hline $18-23$ bulan & 29 & 29 & 40 & 40 \\
\hline$\geq 24$ bulan & 2 & 2 & 4 & 4 \\
\hline \multicolumn{5}{|c|}{ InisiASI menyusu dini } \\
\hline $\mathrm{Ya}$ & 76 & 76 & 67 & 67 \\
\hline Tidak & 24 & 24 & 33 & 33 \\
\hline \multicolumn{5}{|l|}{ ASI ekslusif } \\
\hline Eksklusif $\geq 6$ bl & 43 & 43 & 33 & 33 \\
\hline Tidak eksklusif < $6 \mathrm{bl}$ & 57 & 57 & 67 & 67 \\
\hline \multicolumn{5}{|c|}{ Frekuensi pemantauan pertumbuhan } \\
\hline Ya, timbang $\min 6 x$ & 68 & 68 & 56 & 56 \\
\hline Tidak, timbang <6x & 32 & 32 & 44 & 44 \\
\hline
\end{tabular}

Variabel ASI ekslusif, anak yang tidak mendapat ASI ekslusif lebih banyak baik pada kelompok kontrol maupun kasus. Dimana kelompok kontrol sebesar 57\% dan kelompok kasus sebesar $67 \%$. Frekuensi penimbangan anak lebih banyak pada kategori anak ditimbang minimal 6x dengan persentase 68\% pada kelompok kontrol, dan 56\% pada kelompok kasus.

\section{Analisis Bivariat}

\section{Hubungan Karakteristik Ibu dengan Kejadian Stunting Pada Anak Usia 6-24 Bulan}

Dari analisis pada Tabel 3, didapatkan bahwa pada kelompok kasus lebih banyak terjadi pada usia kehamilan preterm (umur persalinana kurang dari 38 minggu) dengan persentase 54.44\%. Pada variabel usia ibu pada awal kehamilan.

Tabel 3. Hubungan Karakteristik Ibu Dengan Kejadian Stunting

\begin{tabular}{|c|c|c|c|c|c|c|}
\hline \multirow[t]{2}{*}{ Variabel } & \multicolumn{2}{|c|}{$\begin{array}{r}\text { Kontrol } \\
(\mathrm{n}=100)\end{array}$} & \multicolumn{2}{|c|}{ Kasus $(n=100)$} & \multirow[t]{2}{*}{ P-value } & \multirow[t]{2}{*}{$O R$} \\
\hline & $\mathbf{N}$ & $\%$ & $\mathbf{N}$ & $\%$ & & \\
\hline \multicolumn{7}{|l|}{ Usia kehamilan } \\
\hline Preterm & 41 & 45.56 & 49 & 54.44 & 0.256 & 0.723 \\
\hline Aterm & 59 & 53.64 & 51 & 46.36 & & \\
\hline \multicolumn{7}{|l|}{ Usia ibu awal kehamilan } \\
\hline$<20$ tahun & 16 & 42.11 & 22 & 57.89 & 0.197 & - \\
\hline 20-35 tahun & 78 & 53.79 & 67 & 46.21 & & \\
\hline$>35$ tahun & 6 & 35.29 & 11 & 64.71 & & \\
\hline \multicolumn{7}{|c|}{ Tinggi badan ibu awal kehamilan } \\
\hline Normal & 68 & 55.28 & 55 & 44.72 & 0.059 & 1.73 \\
\hline Kurang & 32 & 41.56 & 45 & 58.44 & & \\
\hline
\end{tabular}




\begin{tabular}{|c|c|c|c|c|c|c|}
\hline \multirow[t]{2}{*}{ Variabel } & \multicolumn{2}{|c|}{$\begin{array}{l}\text { Kontrol } \\
(n=100)\end{array}$} & \multicolumn{2}{|c|}{ Kasus $(n=100)$} & \multirow[t]{2}{*}{$P$-value } & \multirow[t]{2}{*}{ OR } \\
\hline & $\mathbf{N}$ & $\%$ & $\mathbf{N}$ & $\%$ & & \\
\hline \multicolumn{7}{|l|}{ Status gizi ibu awal kehamilan (IMT) } \\
\hline Baik & 82 & 53.95 & 70 & 46.05 & $0.047 *$ & 1.95 \\
\hline Kurang & 18 & 37.5 & 30 & 62.5 & & \\
\hline \multicolumn{7}{|l|}{ Status kekurangan energi kronis } \\
\hline Tidak KEK $\geq 23.5$ & 80 & 55.17 & 65 & 44.83 & $0.018^{*}$ & 2.15 \\
\hline Kek $<23.5$ & 20 & 36.36 & 35 & 63.64 & & \\
\hline \multicolumn{7}{|l|}{ Kenaikan berat badan ibu hamil } \\
\hline Sesuai Institute of Medicine (IOM) & 64 & 51.61 & 60 & 48.39 & 0.56 & 1.18 \\
\hline Kurang dari iom & 36 & 47.37 & 40 & 52.63 & & \\
\hline \multicolumn{7}{|l|}{ Frekuensi pemeriksaan kehamilan } \\
\hline Baik $\geq 4$ kali & 91 & 50.56 & 89 & 49.44 & 0.637 & 1.24 \\
\hline Tidak <4 kali & 9 & 45 & 11 & 55 & & \\
\hline \multicolumn{7}{|l|}{ Penanganan persalinan } \\
\hline Tenaga medis & 89 & 50.28 & 88 & 49.72 & 0.825 & 1.10 \\
\hline Tenaga non medis & 11 & 47.83 & 12 & 52.17 & & \\
\hline \multicolumn{7}{|l|}{ Perawatan persalinan } \\
\hline Perawatan & 99 & 49.75 & 100 & 50.25 & 1.00 & - \\
\hline Tidak perawatan & 1 & 100 & 0 & 1 & & \\
\hline
\end{tabular}

Kelompok kasus lebih banyak pada usia ibu lebih dari 35 tahun (64.71\%). Kelompok kasus lebih banyak terjadi pada anak dari ibu yang memiliki tinggi badan kurang dari $150 \mathrm{~cm}$ (58.44\%). Status gizi ibu awal kehamilan berdasarkan perhitungan Indeks Massa Tubuh (IMT) berasosiasi dengan kasus stunting yang ditunjukkan degan nilai $p$-value $(\mathrm{p}<0,05)$ adalah 0.047 dan kasus stunting lebih besar terjadi pada anak dari ibu yang memiliki IMT kurang (62.5\%).

Status KEK menunjukkan $p$-value $(\mathrm{p}<0,05)$ adalah 0.018 yang berarti status KEK berasosiasi dengan kasus stunting. Persentase kasus stunting lebih besar pada ibu yang memiliki KEK <23.5 (63.64\%). Ibu dengan kenaikan berat badan kurang dari rekomendasi Institute of Medicine (IOM) memiliki persentase lebih besar pada kelompok kasus (52.63\%). Ibu yang frekuensi periksa $<4$ kali juga memiliki persentase lebih besar pada kelompok kasus $(55 \%)$. Variabel penanganan untuk kelompok kasus lebih besar terjadi pada kategori tenaga non medis $(52.17 \%)$.

Nilai Odd Ratio (OR) lama kehamilan dengan kategori aterm berisiko 95\% CI (0,723 kali) lebih rendah untuk memiliki anak stunting daripada ibu yang lama kehamilannya masuk dalam kategori preterm. Tinggi badan ibu yang kurang lebih berisiko 1.73 kali memiliki anak stunting. Pada saat periode kehamilan ibu yang memiliki Indeks Massa Tubuh (IMT) kurang, lebih berisiko 95\% CI (1.95 kali) memiliki anak stunting dibandingkan dengan ibu yang memiliki IMT baik. 
Tabel 4. Hubungan Karakteristik Anak Dengan Kejadian Stunting

\begin{tabular}{|c|c|c|c|c|c|c|}
\hline \multirow{2}{*}{ Variabel } & \multicolumn{2}{|c|}{ Kontrol } & \multicolumn{2}{|c|}{$\underline{\text { Kasus }}$} & \multirow{2}{*}{$P$-value } & \multirow[t]{2}{*}{ OR } \\
\hline & $\overline{\mathbf{N}}$ & $\%$ & $\mathbf{N}$ & $\%$ & & \\
\hline \multicolumn{7}{|l|}{ Jenis kelamin anak } \\
\hline Laki-laki & 46 & 44.23 & 58 & 55.77 & 0.089 & - \\
\hline Perempuan & 54 & 56.25 & 42 & 43.75 & & \\
\hline \multicolumn{7}{|l|}{ Usia anak } \\
\hline 6-11 bulan & 38 & 63.33 & 22 & 36.67 & 0.078 & \\
\hline $12-17$ bulan & 31 & 47.69 & 34 & 52.31 & & \\
\hline $18-23$ bulan & 29 & 42.03 & 40 & 57.97 & & \\
\hline$\geq 24$ bulan & 2 & 33.33 & 4 & 66.67 & & \\
\hline \multicolumn{7}{|l|}{ Inisiasi menyusu dini } \\
\hline $\mathrm{Ya}$ & 76 & 53.15 & 67 & 46.85 & 0.159 & 1.55 \\
\hline Tidak & 24 & 42.11 & 33 & 57.89 & & \\
\hline \multicolumn{7}{|l|}{ ASI Eksklusif } \\
\hline Eksklusif $>6$ bl & 43 & 56.58 & 33 & 43.42 & 0.145 & 1.53 \\
\hline Tidak eksklusif $<6 \mathrm{bl}$ & 57 & 45.97 & 67 & 54.03 & & \\
\hline \multicolumn{7}{|c|}{ Frekuensi pemantauan pertumbuhan } \\
\hline Ya (timbang min $6 x)$ & 68 & 54.84 & 56 & 45.16 & 0.08 & 1.66 \\
\hline Tidak (timbang <6x) & 32 & 42.11 & 44 & 57.89 & & \\
\hline
\end{tabular}

Selain itu, ibu yang KEK $<23.5$ berisiko 95\% CI $(2.15$ kali $)$ memiliki anak stunting dibandingkan dengan ibu yang tidak $K E K \geq 23.5$.

Sementara ibu yang pada saat kehamilan frekuensi pemeriksaan kehamilannya kurang dari 4 kali, berisiko 95\% CI (1.24 kali) memiliki anak yang stunting dibandingkan dengan ibu yang frekuensi pemeriksaan kehamilannya minimal 4 kali selama masa kehamilan. Ibu yang memiliki kenaikan berat badan kurang dari rekomendasi Institute of Medicine (IOM) berisiko 1.18 kali memiliki anak stunting dibandingkan ibu yang kenaikan berat badannya sesuai dengan rekomendasi. Pada periode kelahiran, penanganan persalinan yang dilakukan oleh tenaga non medis lebih risiko 1.01 kali memiliki anak stunting dibanding dengan penanganan dengan tenaga medis.

\section{Hubungan Karakteristik Anak dengan Kejadian Stunting}

Dari analisis pada Tabel 4, didapatkan bahwa persentase responden dengan kelompok kasus lebih banyak pada anak laki-laki (55.77\%). Pada variabel usia anak persentase terbesar kelompok kasus berada pada kategori usia lebih besar dari 23 bulan (66.67\%). Anak yang tidak mendapat IMD lebih banyak untuk kelompok kasus daripada anak yang mendapat IMD (57.89\%). Anak yang tidak mendapatkan ASI ekslusif memiliki persentase stunting lebih besar $(54.03 \%)$. Pada frekuensi penimbangan, kelompok kasus lebih banyak terjadi pada anak yang ditimbang kurang dari 6 kali (57.89\%). 
Pada periode usia bawah dua tahun (baduta), anak yang tidak mendapatkan inisiasi menyusu dini berisiko 1.55 kali mengalami stunting dibandingkan dengan anak yang mendapatkan inisiasi menyusu dini. Anak yang tidak mendapatkan ASI ekslusif memiliki risiko 1.53 kali mengalami stunting dibandingkan dengan anak yang mendapatkan ASI ekslusif. Pada variabel kategori pemantauan pertumbuhan (penimbangan di posyandu), anak yang tidak dipantau pertumbuhan dan perkembangannya secara teratur setiap bulan, memiliki risiko 1.66 kali mengalami stunting dibandingkan dengan anak yang dipantau secara rutin setiap bulannya. Pada periode baduta ini dari 3 variabel (IMD, ASI eksklusif, dan Frekuensi pemantauan pertumbuhan) tidak menunjukkan nilai yang signikan ( $\mathrm{p}$-value $>0.05$ ).

\section{Analisis Multivariat}

Tabel 5. Regresi Logistik Hubungan Antara Variabel Dengan Kejadian Stunting

\begin{tabular}{|c|c|c|c|c|c|c|}
\hline Variabel & $\begin{array}{c}\text { Model 1 } \\
\text { OR } \\
\text { pvalue }\end{array}$ & $\begin{array}{l}\text { Model 2 } \\
\text { OR } \\
\text { Pvalue }\end{array}$ & $\begin{array}{c}\text { Model 3 } \\
\text { OR } \\
\text { Pvalue }\end{array}$ & $\begin{array}{c}\text { Model } 4 \\
\text { OR } \\
\text { pvalue }\end{array}$ & $\begin{array}{l}\text { Model } 5 \\
\text { OR } \\
\text { pvalue }\end{array}$ & $\begin{array}{c}\text { Model } 6 \\
\text { OR } \\
\text { pvalue }\end{array}$ \\
\hline \multicolumn{7}{|l|}{ Indeks massa tubuh (IMT) } \\
\hline Kurang $(<18,5)$ & $\begin{array}{r}1.40 \\
0.400\end{array}$ & $\begin{array}{r}1.51 \\
0.308\end{array}$ & $\begin{array}{r}1.44 \\
0.376\end{array}$ & $\begin{array}{l}1.47 \\
0.35\end{array}$ & $\begin{array}{r}1.41 \\
0.389\end{array}$ & $\begin{array}{r}1.32 \\
0.484\end{array}$ \\
\hline Baik $(>=18,5)$ & 1 & 1 & 1 & 1 & 1 & 1 \\
\hline \multicolumn{7}{|l|}{ Status KEK } \\
\hline $\begin{array}{l}\text { KEK }(<23) \\
\text { Tidak KEK }(>=23)\end{array}$ & $\begin{array}{r}1.81 \\
0.121 \\
1\end{array}$ & $\begin{array}{r}1.68 \\
0.178 \\
1\end{array}$ & $\begin{array}{r}1.67 \\
0.188 \\
1\end{array}$ & $\begin{array}{r}1.58 \\
0.24 \\
1\end{array}$ & $\begin{array}{r}1.69 \\
0.172 \\
1\end{array}$ & $\begin{array}{r}1.77 \\
0.136 \\
1\end{array}$ \\
\hline \multicolumn{7}{|l|}{ IMD } \\
\hline Tidak & & $\begin{array}{r}1.55 \\
0.174 \\
1\end{array}$ & $\begin{array}{r}1.491 \\
0.225 \\
1\end{array}$ & $\begin{array}{r}1.49 \\
0.227 \\
1\end{array}$ & & \\
\hline \multicolumn{7}{|l|}{ ASI Eksklusif } \\
\hline $\begin{array}{l}\text { Tidak eksklusif <6bln } \\
\text { Eksklusif }>=6 \mathrm{bl}\end{array}$ & & & $\begin{array}{r}1.27 \\
0.43 \\
1\end{array}$ & $\begin{array}{r}1.18 \\
0.596 \\
1\end{array}$ & & $\begin{array}{r}1.35 \\
0.316 \\
1\end{array}$ \\
\hline \multicolumn{7}{|l|}{ Frekuensi timbang } \\
\hline $\begin{array}{l}\text { Tidak }(<6 x) \\
\text { Ya }(\min 6 x)\end{array}$ & & & & $\begin{array}{r}1.48 \\
0.198 \\
1\end{array}$ & $\begin{array}{r}1.54 \\
0.145 \\
1\end{array}$ & \\
\hline Pseudo R2 & 0.0231 & 0.0298 & 0.0321 & 0.0381 & 0.0308 & 0.0267 \\
\hline $\mathbf{N}$ & 200 & 200 & 200 & 200 & 200 & 200 \\
\hline
\end{tabular}

Pada Tabel 5, terlihat hasil regresi logistik hubungan antara variabel dengan kejadian stunting. Variabel yang dimasukkan ke dalam analisis multivariat adalah variabel yang mempunyai nilai $\mathrm{p}<0,05$ dan variabel yang mempunyai nilai $\mathrm{p}<0,25$. Berikut ini, hasil model yang terbentuk dari analisis multivariat, yaitu: 
Model 1. Kedua variabel tidak berhubungan dengan kejadian stunting dimana nilai $p$-value $>0.05$. Hasil analisis, model ini menunjukkan ibu yang memiliki IMT kurang, berisiko 1.4 kali lebih tinggi untuk memiliki anak stunting dibanding ibu yang memiliki IMT baik. Ibu yang memiliki status KEK $<23$ berisiko memiliki anak stunting 1.8 kali lebih besar dari ibu yang tidak KEK. Model ini berkontribusi sebesar 2.3\% terhadap stunting.

Model 2. Ketiga variabel tidak berhubungan dengan kejadian stunting, dimana didapatkan nilai p-value $>0.05$. Dari hasil analisis, model menunjukkan bahwa ibu yang memiliki IMT kurang, berisiko 95\% CI (1.51 kali) lebih tinggi untuk memiliki anak stunting dibanding dengan ibu yang memiliki IMT baik. Ibu yang memiliki status KEK $<23$ berisiko 1.68 kali lebih tinggi untuk memiliki anak stunting dibanding ibu yang tidak KEK. Anak yang tidak mendapatkan IMD berisiko 1.55 kali mengalami stunting dibanding dengan anak yang mendapat IMD. Model ini berkontribusi sebesar 2.9\% terhadap kejadian stunting. Terdapat 97.1\% faktor lain yang tidak diteliti dalam penelitian ini yang dapat mempengaruhi kejadian stunting.

Model 3. Keempat variabel tidak berhubungan dengan kejadian stunting dikarenakan p-value $>$ 0.05. Dari hasil analisis, model ini menunjukkan bahwa ibu yang memiliki IMT kurang, berisiko 1.44 kali lebih tinggi untuk memiliki anak stunting dibanding dengan ibu yang memiliki IMT baik. Ibu yang memiliki status KEK $<23$ berisiko 1.67 kali lebih tinggi untuk memiliki anak stunting dibanding ibu yang tidak KEK. Anak yang tidak mendapatkan IMD berisiko 1.49 kali mengalami stunting dibanding dengan anak yang mendapat IMD. Anak yang tidak mendapatkan ASI eksklusif berisiko 1.27 kali lebih besar mengalami stunting dibandingkan dengan anak yang mendapatkan ASI ekslusif. Model ini berkontribusi sebesar $3.2 \%$ terhadap kejadian stunting. Terdapat $96.8 \%$ faktor lain yang tidak diteliti dalam penelitian ini yang dapat mempengaruhi kejadian stunting.

Model 4. Kelima variabel tidak berhubungan dengan kejadian stunting, dimana didapatkan nilai p-value > 0.05. Dari hasil analisis, model ini menunjukkan bahwa ibu yang memiliki IMT kurang, berisiko 1.47 kali lebih tinggi untuk memiliki anak stunting dibanding dengan ibu yang memiliki IMT baik. Ibu yang memiliki status KEK $<23$ berisiko 1.58 kali lebih tinggi untuk memiliki anak stunting dibanding ibu yang tidak KEK. Anak yang tidak mendapatkan IMD berisiko 1.49 kali mengalami stunting dibanding dengan anak yang mendapat IMD. Anak yang tidak mendapatkan ASI eksklusif berisiko 1.18 kali lebih besar untuk mengalami stunting dibandingkan dengan anak yang mendapatkan ASI eksklusif. Anak yang ditimbang kurang 
dari 6 kali berisiko 1.48 kali lebih besar untuk mengalami stunting dibandingkan dengan anak yang ditimbang minimal 6 kali sampai saat penelitian dilakukan. Model ini berkontribusi sebesar 3.8\% terhadap kejadian stunting. Terdapat $96.2 \%$ faktor lain yang tidak diteliti dalam penelitian ini yang dapat mempengaruhi kejadian stunting.

Model 5. Ketiga variabel tidak berhubungan dengan kejadian stunting, dimana didapatkan nilai p-value > 0.05. Dari hasil analisis, model ini menunjukkan bahwa ibu yang memiliki IMT kurang, berisiko 1.41 kali lebih tinggi untuk memiliki anak stunting dibanding dengan ibu yang memiliki IMT baik. Ibu yang memiliki status KEK < 23 berisiko 1.69 kali lebih tinggi untuk memiliki anak stunting dibanding ibu yang tidak KEK. Anak yang ditimbang kurang dari 6 kali berisiko 1.54 kali lebih besar mengalami stunting dibandingkan dengan anak yang ditimbang minimal 6 kali. Model ini berkontribusi sebesar 3\% terhadap kejadian stunting. Terdapat $97 \%$ faktor lain yang tidak diteliti dalam penelitian ini yang dapat mempengaruhi kejadian stunting.

Model 6. Ketiga variabel tidak berhubungan dengan kejadian stunting dimana didapatkan nilai p-value > 0.05. Dari hasil analisis, model ini menunjukkan bahwa ibu yang memiliki IMT kurang, berisiko 1.32 kali lebih tinggi untuk memiliki anak stunting dibanding dengan ibu yang memiliki IMT baik. Ibu yang memiliki status KEK < 23 berisiko 1.77 kali lebih tinggi untuk memiliki anak stunting dibanding ibu yang tidak KEK. Anak yang tidak mendapatkan ASI eksklusif berisiko 1.35 kali lebih besar untuk mengalami stunting dibandingkan dengan anak yang mendapatkan ASI eksklusif. Model ini berkontribusi sebesar 2.6\% terhadap kejadian stunting. Terdapat $97.4 \%$ faktor lain yang tidak diteliti dalam penelitian ini yang dapat mempengaruhi kejadian stunting. Keenam model yang sudah dibentuk tersebut, model yang dipilih adalah model 4 karena memiliki nilai R2 yang terbesar. Artinya model yang terbentuk berkontribusi paling besar terhadap kejadian stunting diantara model yang lain. Berdasarkan pertimbangan itu, peneliti memilih model 4 sebagai model yang lebih baik, sehingga variabel yang terdapat dalam model 4 dapat dipakai sebagai bahan pertimbangan dalam melakukan intervensi.

\section{Discussion}

\section{Karakteristik Ibu dan Anak Pada Periode Kehamilan}

Beberapa faktor hubungan karakteristik ibu dan anak pada periode kehamilan dengan kejadian stunting anak usia 6-24 bulan, yaitu:

Pertama, faktor status gizi ibu pada awal kehamilan. Hasil penelitian menunjukkan ada 
hubungan yang bermakna secara statistik antara status gizi pada awal kehamilan (IMT) dengan kejadian stunting pada anak usia 6-24 bulan (nilai $p$ 0,047). Penelitian ini sejalan dengan riset di Uruguay yang menunjukkan bahwa status gizi ibu pada awal kehamilan (kurus memiliki risiko stunting sebesar 2,15 kali lebih besar dibandingkan dengan ibu dengan status gizi pada awal kehamilan normal (Bove et al., 2012). Menurut Barker (2008) status gizi ibu pada awal masa kehamilan merupakan interpretasi dari cadangan (simpanan) nutrisi ibu sebelum hamil yang sangat dibutuhkan janin di dalam kandungan untuk tumbuh dan berkembang (Barker DJP, 2008). Akahoshi menambahkan bahwa meskipun asupan meningkat selama kehamilan tetapi dengan status gizi ibu hamil yang buruk berhubungan dengan penurunan berat dan luas area permukaan plasenta yang dapat membatasi penyerapan nutrisi dari ibu hamil kepada janin (Akahoshi et al., 2016).

Kedua, faktor status kurang energi kronis. Berdasarkan dari hasil penelitian ini, riwayat kekurangan energi kronis (KEK) saat hamil secara statistik berhubungan dengan kejadian stunting pada anak usia 6-24 bulan dengan p-value 0.018. Penelitian ini sejalan dengan penelitian yang dilakukan Sartono (2014) di Kota Yogyakarta, yang hasilnya menyatakan ada hubungan antara kekurangan energi kronis saat hamil dengan kejadian stunting pada balita usia 6-24 bulan (Sartono and Nurdiati, 2013).

Ketiga, faktor frekuensi pemeriksaan kehamilan. Pemeriksaan kehamilan (ANC) yang bertujuan memantau kesehatan ibu hamil dan janinnya mewajibkan tiap ibu hamil memeriksakan kehamilannya pada petugas kesehatan minimal 4 kali dengan pola $1: 1: 2$, yakni pemeriksaan 1 kali pada trimester I, 1 kali pada trimester II, dan 2 kali pada trimester III (Kemenkes RI., 2011). Hasil analisis univariat menunjukkan ibu yang melakukan pemeriksaan kehamilan sesuai dengan anjuran pemerintah minimal 4 kali persentasenya lebih besar. Pada responden kelompok kontrol persentasenya sebesar 91\% dan kelompok kasus persentasenya sebesar $89 \%$. Hal ini menunjukkan bahwa kesadaran akan pentingnya pemeriksaan kesehatan selama hamil pada lokasi penelitian ini sudah baik. Pada hasil analisis bivariat, menunjukkan tidak ada hubungan yang bermakna antara frekuensi pemeriksaan kehamilan dengan kejadian stunting, hasil uji statistik diperoleh nilai $\mathrm{p}=0.637$. Tidak adanya hubungan itu, dimungkinkan karena tingkat kesadaran masyarakat dalam pemeriksaan kehamilan di lokasi penelitian sudah tinggi, sehingga dengan melakukan pemeriksaan kehamilan, gangguan ataupun keluhan selama hamil dapat segera ditangani oleh petugas kesehatan. Penelitian ini sejalan dengan penelitian di Nepal yang dilakukan (Paudel et al., 2012) dan (Ramli et al., 2009) di Maluku Utara yang juga menyatakan bahwa tidak ada hubungan antara frekuensi kunjungan 
pemeriksaan kehamilan dengan kejadian stunting.

Keempat, faktor kenaikan berat badan ibu pada saat kehamilan. Hasil penelitian ini, tidak terdapat hubungan yang bermakna secara statistik antara kenaikan berat badan ibu selama kehamilan dengan kejadian stunting $(\mathrm{p}>0,05)$. Ibu yang memiliki kenaikan berat badan kurang dari IOM berisiko 1.18 kali memiliki anak stunting dibandingkan ibu yang kenaikan berat badannya sesuai dengan rekomendasi IOM.

\section{Karakteristik Ibu dan Anak Pada Periode Persalinan}

Beberapa faktor hubungan karakteristik ibu dan anak pada periode persalinan dengan kejadian stunting anak usia 6-24 bulan, yaitu: Pertama, faktor penanganan persalinan. Pada beberapa desa yang termasuk dalam lokasi Program Kesehatan dan Gizi Berbasis Masyarakat (PKGBM), setiap ibu hamil dari keluarga miskin akan mendapat bantuan biaya persalinan dengan catatan persalinnya dilakukan oleh petugas kesehatan.

Kedua, faktor, perawatan persalinan. Perawatan persalinan pada masa nifas oleh tenaga kesehatan sangat penting dilakukan untuk menghindari risiko yang mungkin terjadi pada masa itu, antara lain: anemia, pre eklampsialeklampsia, perdarahan post partum, depresi masa nifas, dan infeksi masa nifas. Diantara risiko tersebut, ada dua yang paling sering mengakibatkan kematian pada ibu nifas, yakni infeksi dan perdarahan. Hal ini sejalan dengan penelitian yang menyatakan bahwa kejadian komplikasi persalinan ibu melahirkan dengan kualitas pelayanan kesehatan yang tidak baik berisiko lebih besar untuk mengalami komplikasi dibanding ibu yang mendapatkan kualitas pelayanan yang baik (Misar et al., 2012).

Ketiga, faktor konseling pemberian makan bayi dan anak (PMBA). Penelitian yang dilakukan Agbozo et al., di Ghana menunjukkan bahwa pengasuh anak dalam program Community Based Growth Promotion (CBGP) yang mendapat pelayanan pemantauan pertumbuhan dan konseling oleh relawan/kader masyarakat yang telah dilatih dinas kesehatan setempat memiliki pengetahuan IYCF (infant and young child feeding), inisiasi menyusu dini, ASI eksklusif, keragaman makanan dan ketepatan waktu pemberian makan lebih tinggi, dibandingkan pengasuh anak dalam program GMP (Growth Monitoring and Promotion) yang disediakan oleh tenaga kesehatan (Agbozo, Colecraft and Ellahi, 2016).

\section{Karakteristik Ibu dan Anak Pada Periode Usia Bawah Dua Tahun}

Beberapa faktor hubungan karakteristik ibu dan anak pada periode usia bawah dua tahun dengan kejadian stunting anak usia 6-24 bulan, yaitu:

Pertama, faktor Inisiasi Menyusu Dini (IMD). Ibu dan bayi yang berhasil melaksanakan IMD sesuai anjuran memungkinkan bayi mendapatkan kolustrum pada awal- 
awal menyusu. Penelitian yang dilakukan Teshome menunjukkan bahwa anak yang tidak mendapatkan kolustrum lebih berisiko tinggi terhadap stunting. Hal ini dimungkinkan karena kolustrum yang hanya didapatkan pada awal proses menyusui dapat memberikan efek perlindungan dari penyakit infeksi dan kekurangan gizi pada bayi baru lahir (Teshome et al., 2010).

Kedua, faktor pemberian ASI eksklusif. Kajian global membuktikan bahwa pemberian ASI eksklusif adalah intervensi kesehatan yang mempunyai dampak terbesar terhadap keselamatan balita yaitu dapat mencegah kematian balita sebesar 13\%. Melaksanakan IMD dapat mencegah 22\% kematian pada bayi usia 0-28 hari (neonatus). Dengan memberikan MPASI yang tepat dan berkualitas dapat menurunkan kematian balita sebesar 6\% (Kemenkes RI.,2011). Menurut Hien \& Kam yang dikutip oleh Anisa Paramitha, risiko menjadi stunting 3.7 kali lebih tinggi pada balita yang tidak diberikan ASI eksklusif dibandingkan dengan balita yang diberi ASI eksklusif (Anisa, 2012).

Ketiga, faktor pemantauan pertumbuhan. Keberadaan faktor ini penting dilakukan untuk menentukan gangguan pertumbuhan sedini mungkin pada balita dan dilakukan secara teratur setiap bulannya. Pertumbuhan yang normal akan menggambarkan keadaan kesehatan anak yang baik (Fadlyana et al., 2016).

\section{Hasil Analisis Multivariat}

Dari hasil pengembangan perhitungan dengan regresi logistik menggunakan 6 model tersebut, maka yang memungkinkan dipakai sebagai rekomendasi dalam pencegahan dan penanggulangan stunting di Kota Surabaya, didapatkan model 4 dengan nilai R2 sebesar 0.0381, di mana 5 variabel yang digunakan mewakili setiap periode dalam penelitian ini. Hal ini sesuai dengan Undang Undang Nomor 36 Tahun 2009 tentang Kesehatan disebutkan bahwa upaya perbaikan gizi dilakukan pada seluruh periode kehidupan dengan prioritas utama pada kelompok rawan gizi yaitu: bayi, anak balita, remaja perempuan, ibu hamil dan menyusui.

Sementara itu, hasil analisis hubungan antar periode dan antar variabel pada periode 1000 HPK (kehamilan, persalinan, dan usia baduta), hasilnya secara statistik diharapkan memberikan gambaran dalam perencanan dan upaya intervensi pencegahan dan penurunan stunting. Pada perjalanannya, ternyata hanya dua periode dan lima variabel yang secara persyaratan dan analisa statistik yang memungkinkan untuk dianalis.

Periode kehamilan dan periode usia baduta tidak menunjukkan nilai yang signifikan pada tahap analisis path, akan tetapi pada tahap asosiasi antara variabel kehamilan dan 
variabel baduta terdapat nilai yang signifikan. Variabel kategori ASI ekslusif berasosiasi dengan kategori IMT dengan nilai p-value 0.005. Kategori status KEK juga berasosiasi dengan ASI eksklusif dengan nilai p-value 0.024 dan variabel kategori frekuensi pemantauan pertumbuhan dengan nilai $p$-value 0.047 .

Variabel-variabel yang memiliki nilai asosiasi signifikan tersebut dapat dikatakan berhubungan antar variabelnya sehingga dapat dikatakan kategori IMT dan ASI eksklusif memiliki interaksi. Variabel status KEK berinteraksi atau berhubungan dengan variabel ASI eksklusif dan variabel pemantauan pertumbuhan. Sehingga ketika akan melihat kasus stunting, ketiga varaibel tersebut dapat dipertimbangkan.

\section{CONCLUSION}

Karakteritik ibu dan anak pada periode 1000 HPK yang jadi faktor risiko (prediktor penentu) kejadian stunting ialah: status gizi awal kehamilan, status KEK, kenaikan berat badan selama hamil, frekuensi pemeriksaan kehamilan, penanganan persalinan, inisiasi menyusu dini, ASI eksklusif, dan pemantauan pertumbuhan. Adapun faktor karakteristik ibu dan anak yang memiliki pengaruh paling besar dengan kejadian stunting ialah kenaikan berat badan ibu selama kehamilan karena memiliki nilai statistik z terbesar (0.867).

Diharapkan upaya perbaikan kesehatan dan gizi pada kasus stunting harus dilakukan pada seluruh periode kehidupan dengan prioritas utama pada kelompok rawan gizi (bayi, anak balita, remaja perempuan, ibu hamil dan dan bersalin/menyusui). Untuk itu, perlu kerjasama lintas program dalam intervensi gizi spesifik dan kerjasama lintas sektoral berupa intervensi gizi sensitif. Untuk pelaksanaan intervensi harus dilakukan secara terpadu dan berkelanjutan disemua periode (kehamilan, persalinan dan usia baduta).

\section{ACKNOWLEDGMENTS}

Ucapan terimakasih kepada pihak-pihak terkait terutama pada Universitas Airlangga yang telah membantu dalam proses penelitian.

\section{REFERENCES}

Agbozo, F., Colecraft, E. and Ellahi, B. (2016) 'Impact of type of child growth intervention program on caregivers' child feeding knowledge and practices: a comparative study in Ga West Municipality, Ghana', Food Science and Nutri- tion, 4(4), pp. 562-572. doi: $10.1002 /$ fsn3.318.

Akahoshi, E. et al. (2016) 'Association of maternal pre-pregnancy weight, weight gain during pregnancy, and smoking with small-for- gestational-age infants in Japan', Early 
Human Development, 92, pp. 33-368. doi: 10.1016/j.earlhumdev.2015.10.022.

Anisa, P. (2012) 'Faktor-faktor Yang Berhubungan dengan Kejadian Stunting pada Balita Usia 25-60 Bulan di Kelurahan Kalibaru Depok Tahun 2012', Universitas Indonesia.

Badan Pusat Statistik Kota Surabaya (2018) Surabaya dalam Angka 2017. Surabaya.

Barker DJP (2008) Nutrition in The Womb: How Better Nutrition During Development Will Prevent Heart Disease, Diabetes, and Stroke. USA: The Barker Foundation.

Bove, I. et al. (2012) 'Stunting, overweight and child development impairment go hand in hand as key problems of early infancy: Uruguayan case', Early Human Development, 88((9)), pp. 747-751. doi: 10.1016/ j.earlhumdev.2012.04.002.

Fadlyana, E. et al. (2016) 'Pola Keterlambatan Perkembangan Balita di daerah Pedesaan dan Perkotaan Bandung, serta Faktor-faktor yang Mempengaruhinya', Sari Pediatri, 4((4)), pp. 168-75. doi: 10.14238/sp4.4.2003.168- 75.

Haddad L (2016) Global Nutrition Report 2016: From Promise to Impact; Ending Malnutrition By 2030, Impact. doi: 10.2499/9780896295841.

Kemenkes RI. (2011) Keputusan Menteri Kesehatan Republik Indonesia Nomor: 1995/Menkes/SK/ XII/2010 tentang Standar Antropometri penilaian status gizi anak. Jakarta.

Kementerian Kesehatan Republik Indonesia (2018) 'Buletin Stunting', Kementerian Kesehatan Republik Indonesia, 301(5), pp. 1163-1178.

Lemeshow S., Hosmer DW., K. J. \& L. S. (1997) Besar sampel dalam penelitian kesehatan. (Alih bahasa Pramono D., Kusnanto H.). Yogyakarta: Gadjah Mada University Press.

Misar, Y. et al. (2012) 'Faktor Risiko Komplikasi Persalinan Pada Ibu Melahirkan di Kota Gorontalo Utara Tahun 2012', Pasca.Unhas.Ac.Id/Jurnal/Files/032F3Fbb5039C51E91E59B0C0Bbfda22.Pdf.

De Onis, M. et al. (2013) 'The world health organization's global target for reducing childhood stunting by 2025: Rationale and proposed actions', Maternal and Child Nutrition, 9, pp. 6-26. doi: 10.1111/ mcn.12075.

Paudel, R. et al. (2012) 'Risk factors for stunting among children: A community based case control study in Nepal', Kathmandu University Medical Journal, 39((3)), pp. 18-24. 
Program Nasional Pemberdayaan Masyarakat Mandiri (PNPM) (2013) Proyek Kesehatan dan Gizi Berbasis Masyarakat (PKGBM) Untuk Mencegah Stunting. Jakarta.

Ramli et al. (2009) 'Prevalence and risk factors for stunting and severe stunting among underfives in North Maluku province of Indonesia', BMC Pediatrics, 9, p. 64. doi: 10.1186/1471- 2431-9-64.

Riset Kesehatan Dasar (RISKESDAS) (2019) 'Laporan Nasional Riskesdas 2018', Badan Penelitian dan Pengembangan Kesehatan Riset.

RISKESDAS (2013) 'Riset Kesehatan Dasar; Badan Penelitian dan Pengembangan Kesehatan Kementerian Kesehatan RI Tahun2010’, Laporan Nasional 2010.

Riyanto, A. (2011) Aplikasi Metodologi Penelitian Kesehatan. Cet. 2. Yogyakarta: Nuha Medika.

Sartono and Nurdiati, D. S. (2013) 'Hubungan kurang energi kronis ibu hamil dengan kejadian stunting pada anak usia 6-24 bulan di Kota Yogyakarta', Universitas Gadjah Mada.

Teshome, B. et al. (2010) 'Magnitude and determinants of stunting in children underfive years of age in food surplus region of Ethiopia: The case of West Gojam Zone', Ethiopian Journal of Health Development, 23 ((2)), pp. 98-106. doi: 10.4314/ ejhd.v23i2.53223.

WHO (2010) Nutrition landscape information systems (NLIS): Country profiel indicators Interpretation Guide, Nutrition Landacape Information System. doi: 10.1159/000362780.Interpretation. 